\title{
The association between red and processed meat consumption and iron intakes and status among British adults
}

\author{
Sigrid Gibson ${ }^{1, *}$ and Margaret Ashwell ${ }^{2}$ \\ ${ }^{1}$ SiG-Nurture Nutrition Consultancy, 11 Woodway, Guildford, Surrey, GU1 2TF, UK: ${ }^{2}$ Ashwell Associates, \\ Ashwell Street, Ashwell, Herffordshire, SG7 5PZ, UK
}

Submitted 21 May 2002: Accepted 14 November 2002

\begin{abstract}
Objective: To examine the association between consumption of red and processed meat (RPM) and iron intakes and status in adults.

Design: Further analysis of the Dietary and Nutritional Survey of British Adults, a cross-sectional study of 2197 adults aged 16-64 years carried out in 1986/7.

Subjects and methods: Adults (836 men and 838 women) with serum ferritin measurements, who were not taking iron supplements, were classified into four groups according to RPM consumption (from 7-day weighed records). Iron absorbed was estimated from equations based on haem and non-haem iron and the influence of iron stores.

Results: Women who ate least meat $\left(<90 \mathrm{~g} \mathrm{day}^{-1}\right)$ had three times the risk of a low iron intake (below the Lower Reference Nutrient Intake) compared with high consumers of RPM $\left(>140 \mathrm{~g} \mathrm{day}^{-1}\right)$. Men who ate no RPM also had a higher risk of low iron intake. Using an estimate of minimal values for iron losses, there was a twofold difference in the potential risk of negative iron balance between women non-RPM consumers and high RPM consumers. Status measurements indicated that, among women, anaemia was least prevalent (6\%) among high consumers compared with $12-14 \%$ among average RPM consumers. Inverse trends were also observed for serum ferritin in both sexes.

Conclusions: Low consumption of RPM has implications for iron intakes and iron status in men and women, since the risk of negative iron balance and its consequences are increased. Dietary messages must consider these implications and provide appropriate advice.
\end{abstract}

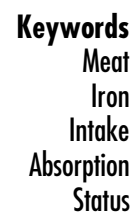

The consumption of red meat appears to be in long-term decline $^{1}$. The consumption of beef has fallen progressively almost every year since 1987, with a larger than usual fall in 1996 following the announcement of a possible link between bovine spongiform encephalopathy (BSE) and new variant Creutzfeld-Jacob disease ${ }^{2}$. Factors such as vegetarianism and the trend for non-meat eating, the quest for greater convenience, and perceived health risks such as cardiovascular disease and cancer may all have contributed to the decline.

A link between red meat and colorectal cancer was originally postulated from work on the carcinogenicity of heterocyclic amines ${ }^{3}$, supported to some extent by epidemiological studies ${ }^{4,5}$. In 1997, the World Cancer Research Fund (WCRF)'s report on Food, Nutrition and The Prevention of Cancer: A Global Perspective recommended that 'if eaten at all, red meat [should] provide less than $10 \%$ of total energy'. The advice to individuals was to 'limit intake of red meat to less than $80 \mathrm{~g}$ daily'. However, the quantitative basis for the recommendation to restrict intake to $80 \mathrm{~g} \mathrm{day}^{-1}$ was not given ${ }^{6}$.
In 1998, a Working Group report by the Department of Health's Committee on the Medical Aspects of Food and Nutrition Policy (COMA), entitled Nutritional Aspects of the Development of Cancer $^{7}$, concluded that 'lower consumption of red and processed meat would probably reduce the risk of colorectal cancer'. The Working Group recommended that '[an] individual's consumption of red and processed meat should not rise; that higher consumers should consider a reduction; and as a consequence of this the population average will fall. Adults with intakes of red and processed meats greater than the current average (90 g/day cooked weight) especially those in the upper reaches of the distribution of intakes (above $140 \mathrm{~g} /$ day cooked weight) where the scientific data are more robust, might benefit from, and should consider a reduction in intake. It is not recommended that adults with intakes below the current average should reduce their intakes. The wider nutritional implications of any reduction should be assessed... Meat and meat products are a valuable source of a number of nutrients, including iron, whose average intake in some sectors of the population is low.' 
It is recognised that one of the main disadvantages of reducing the consumption of red and processed meat (RPM) is the potential impact on iron intake and status. Iron is one of the most marginal nutrients in the UK food supply, and women of childbearing age, in particular, are most vulnerable to iron deficiency 8,9 . The functional consequences of iron deficiency are many, and some of the longterm effects still need to be elucidated. There is a staged process whereby the individual progresses from a position of adequate iron status, through iron deficiency, to irondeficiency anaemia (IDA) ${ }^{10}$. The general symptoms of IDA are tiredness, lack of energy, and poor work performance due to the reduction in circulating haemoglobin $(\mathrm{Hb})$ and other iron-containing enzymes and myoglobin.

Meat is a rich source of haem iron, which has higher bioavailability than non-haem iron. Absorption of haem iron is less affected by enhancers and inhibitors in the diet. It is usually assumed that an individual's iron status depends more on iron stores and the amount of bioavailable iron in the diet than on total iron intake ${ }^{11,12}$.

Although the COMA report ${ }^{7}$ did not specify that adults with intakes below the current average of $90 \mathrm{~g} \mathrm{day}^{-1}$ should reduce their consumption, the recommendations from this report and those from the WCRF report have often been communicated as general advice for everyone to eat less $\mathrm{RPM}^{13}$. The implications of a decline in RPM consumption on iron intakes and iron status are the focus of this study. We have used the data on British adults in $1986 / 7^{9}$ to investigate iron intakes and iron status in groups consuming different amounts of RPM, as an indication of the implications of a lower RPM consumption in today's population.

\section{Methods}

\section{Subjects and assessment methods in the original survey}

The Dietary and Nutritional Survey of British Adults (DNSBA) ${ }^{9}$ was the predecessor to a new rolling programme of National Diet and Nutrition Surveys (NDNS) jointly funded by the Ministry of Agriculture, Fisheries and Food and the Department of Health. The aim of the DNSBA was to collect dietary and health information on a national sample of adults aged 16-64 years living in households in Britain in 1986/7. Each participant weighed and recorded all items of food and drink, as consumed, over 7 days using the cumulative weighing technique. Detailed descriptions were collected, including type and cut of meat and whether lean or fat; leftovers were also weighed and described. Information was also requested on brands of ready meals and recipes of home-made dishes. Fieldworkers visited frequently during the survey week to deal with any problems. Energy and nutrient intakes were calculated from the food records using a specially constructed nutrient database covering some
5000 foods, including manufactured items and recipes provided by participants.

Approximately $79 \%$ of men and women completing diary records consented to provide a non-fasting sample $(20 \mathrm{ml})$ of venous blood for haematological assessment. Blood was collected by qualified medical personnel in the subject's own home and transferred into tubes pretreated with ethylenediaminetetraacetic acid before being sent to the Department of Haematology at Birmingham General Hospital. Haematological measurements were carried out on the commercial Coulter counter system. External validation in the regional quality assurance (EQA) scheme showed no evidence of bias. Serum ferritin was analysed using the routine commercial two-site immunoradiometric assay (Ciba Corning). Assessment of the coefficient of variation and bias indicated that the results were acceptable throughout the survey'. We used cut-offs of $<25 \mu \mathrm{gl}^{-1}, \quad<20 \mu \mathrm{gl}^{-1}, \leq 15 \mu \mathrm{gl}^{-1}$ and $10 \mu \mathrm{gl}^{-1}$ to identify people with low iron stores (the three upper values for men and the three lower values for women) and World Health Organization criteria to classify those who were anaemic $\left(\mathrm{Hb}<12 \mathrm{~g} \mathrm{dl}^{-1}\right.$ for women and $\mathrm{Hb}<13 \mathrm{~g} \mathrm{dl}^{-1}$ for men).

\section{Estimation of RPM consumption}

The COMA Working Group, in deriving the basis for their recommendations ${ }^{7}$, had used the raw data from the $\mathrm{DNSBA}^{9}$ to calculate the proportion of RPM in the average diet $\left(90 \mathrm{~g} \mathrm{day}^{-1}\right)$. As the individual food code data were not available to us, a factor was applied to each of the 11 meat-containing food groups (Table 1) to arrive at a similar overall estimate of RPM consumption (mean $90 \mathrm{~g} \mathrm{day}^{-1}$ : $70 \mathrm{~g} \mathrm{day}^{-1}$ for women, $110 \mathrm{~g} \mathrm{day}^{-1}$ for men). This was used to classify individuals into four groups: (1) non-consumers; (2) below-average consumers $\left(<90 \mathrm{~g} \mathrm{day}^{-1}\right)$; (3) above-average consumers (90$\left.140 \mathrm{~g} \mathrm{day}^{-1}\right)$; and (4) high consumers $\left(>140 \mathrm{~g} \mathrm{day}^{-1}\right)$.

\section{Iron from RPM and proportions of haem and non-haem iron}

These were calculated directly from the DNSBA values for the contribution of iron from the 11 meat-containing food groups (Table 2). Meat and meat products provided $2.76 \mathrm{mg} \mathrm{Fe}$ day $^{-1}$, of which $0.2 \mathrm{mg}$ came from the codes for poultry and poultry products. We assumed that $10 \%$ of the iron in sausages and $50 \%$ of the iron in meat pies came from non-meat sources (e.g. cereal), leaving an estimated $2.41 \mathrm{mg} \mathrm{Fe} \mathrm{day}{ }^{-1}$ from RPM. Approximately $40 \%$ of the iron from RPM was assumed to be haem iron ${ }^{14}$, together with $40 \%$ of the iron from poultry. The remaining $60 \%$ of iron from meat and poultry and the iron from all other foods was assumed to be non-haem iron. On this basis, haem iron constituted $9 \%$ of total iron. This is between the estimate of $10 \%$ from the household diet in the late $1970 \mathrm{~s}^{15}$ and $6 \%$ from the more recent survey of people over 65 years of age ${ }^{16}$. 
Table 1 Estimates of red and processed meat (RPM) consumption

\begin{tabular}{|c|c|c|c|}
\hline Meat group & $\begin{array}{l}\text { Mean consumption } \\
\text { of meat and meat dishes } \\
\text { from DNSBA }\left(\mathrm{g} \mathrm{day}^{-1}\right)\end{array}$ & $\begin{array}{l}\text { Estimated } \\
\text { RPM (\%) }\end{array}$ & $\begin{array}{c}\text { Estimated } \\
\text { RPM }\left(\mathrm{g} \mathrm{day}^{-1}\right)\end{array}$ \\
\hline Bacon and ham & 16 & 95 & 15 \\
\hline Beef and veal & 37 & 95 & 35 \\
\hline Lamb & 9 & 95 & 9 \\
\hline Pork & 10 & 95 & 9 \\
\hline Coated chicken & 2 & 0 & 0 \\
\hline Chicken/turkey dishes & 23 & 0 & 0 \\
\hline Liver and products & 4 & 95 & 4 \\
\hline Burgers/kebabs & 7 & 95 & 6 \\
\hline Sausages & 11 & 65 & 7 \\
\hline Meat pies and pastries & 19 & 10 & 2 \\
\hline Other meat and meat products & 13 & 25 & 3 \\
\hline Total & 151 & & 90 \\
\hline
\end{tabular}

DNSBA - Dietary and Nutritional Survey of British Adults ${ }^{9}$.

\section{Estimation of iron absorbed}

From the amounts of haem and non-haem iron in the diet (as calculated above) we estimated the amount of iron absorbed (AbFe) by each individual, using algorithms based on the studies of Hallberg et al. ${ }^{17}$ and Hulten et al. ${ }^{18}$. These take into account the impact of individual iron stores (as measured by serum ferritin) on the fractional absorption of haem and non-haem iron. We used the same equations for both sexes since men and women have been shown to absorb the same proportion of iron from the diet at the same iron status ${ }^{17,18}$. The amount of total iron absorbed was then calculated as the sum of the amounts of haem iron and non-haem iron multiplied by their respective absorption.

According to Hallberg's formulae, the relationships between the absorption of haem and non-haem iron and serum ferritin are described by the following equations:

$$
\begin{aligned}
& (\log ) \text { haem absorption }(\%) \\
& =1.9897-0.3092(\log ) \text { serum ferritin }
\end{aligned}
$$

and

$$
\begin{aligned}
& (\log ) \text { non-haem absorption }(\%) \\
& =2.6974-1.0432(\log ) \text { serum ferritin. }
\end{aligned}
$$

Table 2 Total iron from meat groups

\begin{tabular}{lcc}
\hline Meat group & $\begin{array}{c}\text { Iron from DNSBA } \\
\left(\text { mg day }^{-1}\right)\end{array}$ & $\begin{array}{c}\text { Estimated } \\
\text { iron from RPM } \\
\left(\text { mg day }^{-1}\right)\end{array}$ \\
\hline Bacon and ham & 0.20 & 0.20 \\
Beef and veal & 0.81 & 0.81 \\
Lamb & 0.16 & 0.16 \\
Pork & 0.11 & 0.11 \\
Coated chicken & 0.02 & 0 \\
Chicken/turkey dishes & 0.18 & 0 \\
Liver and products & 0.37 & 0.37 \\
Burgers/kebabs & 0.15 & 0.15 \\
Sausages & 0.16 & 0.14 \\
Meat pies and pastries & 0.27 & 0.14 \\
Other meat and meat products & 0.34 & 0.34 \\
Total & 2.76 & 2.41 \\
\hline
\end{tabular}

RPM - red and processed meat; DNSBA - Dietary and Nutritional Survey of British Adults ${ }^{9}$.
These formulae were applied to the DNSBA data for serum ferritin values between 10 and $100 \mu \mathrm{gl}^{-1}$. Below $10 \mu \mathrm{gl}^{-1}$, the absorption of both forms of iron is about $50 \%$ and does not increase further. At a serum ferritin level of $100 \mu \mathrm{gl}^{-1}$, absorption of haem and non-haem iron was $23.5 \%$ and $4.1 \%$, respectively. These values are almost identical to the absorption factors quoted by Monsen et al. for women with replete iron stores $(23 \%$ and $5 \%$ for haem and non-haem iron, respectively) ${ }^{14,19}$. For serum values above $100 \mu \mathrm{gl}^{-1}$ absorption was taken to be these minimum values (see Fig. 1).

\section{Estimation of iron requirements (LRNI)}

These were taken from the values set by the Department of Health in the report on Dietary Reference Values (DRVs) in $1991^{20}$. The Lower Reference Nutrient Intake (LRNI) for men was $6.1 \mathrm{mg} \mathrm{day}^{-1}$ for those aged $16-18$ years, and $4.7 \mathrm{mg} \mathrm{day}^{-1}$ for those aged 19 years and over. LRNI for women was $8 \mathrm{mg} \mathrm{day}^{-1}$ for women under 50 years and $4.7 \mathrm{mg} \mathrm{day}^{-1}$ for women aged over 50 years.

\section{Estimation of iron losses and risk of negative iron balance}

Mean iron losses in men and women are quoted as $1.56 \mathrm{mg} \mathrm{day}^{-1}$ for menstruating women and $0.86 \mathrm{mg} \mathrm{day}^{-1}$

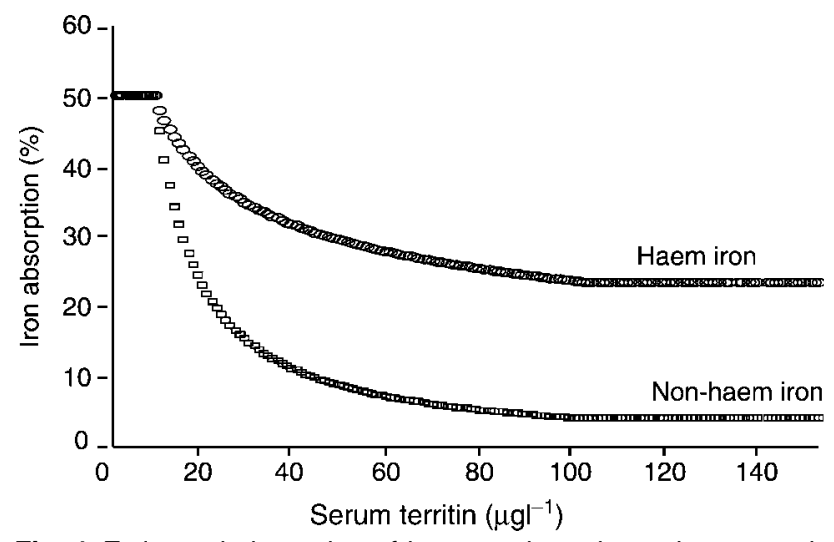

Fig. 1 Estimated absorption of haem and non-haem iron according to serum ferritin level (using Hallberg's equations) 
for men and older women (50 years and over) ${ }^{20}$. These losses comprise $0.86 \mathrm{mg}$ endogenous loss, plus (for women of reproductive age) a menstrual loss equivalent to $0.7 \mathrm{mg} \mathrm{Fe} \mathrm{day}^{-1}$. We used these figures to estimate minimal iron losses in the same manner as that used in establishing the LRNI (i.e. two standard deviations (2SD) below the mean iron loss). This gave us values for minimal losses of $1.092 \mathrm{mg} \mathrm{day}^{-1}$ for women under 50 years and $0.602 \mathrm{mg} \mathrm{day}^{-1}$ for older women and men. We classified the population at potential risk of negative iron balance as the percentage of individuals with estimated absorbable iron (AbFe) below these minimum iron losses.

\section{Sample and statistics}

This study is based on a sample of 1674 (836 men and 838 women) who had measurements of iron status (serum ferritin). People taking iron supplements were excluded from the analysis.

Differences between RPM groups were compared using one-way analysis of variance. Chi-square tests were used for comparison of prevalence, with a test for linear trend where appropriate. Values of $P<0.05$ were taken as significant although actual $P$-values are quoted in the tables.

\section{Results}

\section{Iron intakes of groups of men and women according to RPM consumption}

The cut-offs chosen were those identified in the COMA report $^{7}$ : $90 \mathrm{~g} \mathrm{day}^{-1}$ corresponding to average consumption and $>140 \mathrm{~g} \mathrm{day}^{-1}$ corresponding to high consumption. Not surprisingly, more men than women were classified as high consumers (27\% of men vs. $7 \%$ of women; Tables 3 and 4).

Iron intakes rose with increasing consumption of RPM ( $P<0.0001$ among men, $P=0.002$ among women $)$ and were more than $15 \%$ higher among high RPM consumers $\left(>140 \mathrm{~g} \mathrm{day}^{-1}\right)$ than low consumers $\left(<90 \mathrm{~g} \mathrm{day}^{-1}\right)$.

\section{Prevalence of low iron intakes according to RPM consumption}

The report on DRVs ${ }^{20}$ defines the LRNI as a theoretical level (2SD below the estimated average requirement) at which $97.5 \%$ of individuals are unlikely to be consuming adequate amounts. Therefore, if the percentage of the population who is below the LRNI exceeds 2.5\%, this can be taken to indicate a potential shortfall in iron intakes.

Table 3 Mean red and processed meat (RPM) consumption, iron intake and sources of iron according to level of RPM consumed (men only)

\begin{tabular}{|c|c|c|c|c|c|c|}
\hline & \multicolumn{4}{|c|}{ RPM consumption } & \multirow[b]{2}{*}{$\begin{array}{l}\text { Group total } \\
(n=836)\end{array}$} & \multirow[b]{2}{*}{$\begin{array}{c}P \text {-value } \\
\text { (ANOVA) }\end{array}$} \\
\hline & $\begin{array}{c}\text { Non-consumers } \\
(n=13)\end{array}$ & $\begin{array}{c}<90 \text { g day }^{-1} \\
(n=335)\end{array}$ & $\begin{array}{c}90-140 \mathrm{~g} \mathrm{day}^{-1} \\
(n=264)\end{array}$ & $\begin{array}{c}>140 \mathrm{~g} \mathrm{day}^{-1} \\
(n=224)\end{array}$ & & \\
\hline \multicolumn{7}{|c|}{ RPM consumption ( g day $^{-1}$ ) } \\
\hline Mean & 0 & 59 & 113 & 188 & 110 & $<0.0001$ \\
\hline Median & 0 & 62 & 111 & 177 & 102 & \\
\hline 25th percentile & 0 & 46 & 101 & 155 & 66 & \\
\hline 75th percentile & 0 & 76 & 126 & 207 & 144 & \\
\hline \multicolumn{7}{|c|}{ Iron from RPM (mg) } \\
\hline Mean & 0 & 1.8 & 3.1 & 4.7 & 3.0 & $<0.0001$ \\
\hline Median & 0 & 1.6 & 2.8 & 4.2 & 2.6 & \\
\hline 25th percentile & 0 & 1.1 & 2.3 & 3.3 & 1.7 & \\
\hline 75th percentile & 0 & 2.2 & 3.6 & 5.5 & 3.8 & \\
\hline \multicolumn{7}{|c|}{ Iron from poultry (mg) } \\
\hline Mean & 0.3 & 0.2 & 0.2 & 0.2 & 0.2 & NS \\
\hline Median & 0 & 0.2 & 0.1 & 0.1 & 0.1 & \\
\hline 25th percentile & 0 & 0 & 0 & 0 & 0 & \\
\hline 75th percentile & 0.5 & 0.4 & 0.3 & 0.3 & 0.3 & \\
\hline \multicolumn{7}{|c|}{ Iron from non-meat sources (mg) } \\
\hline Mean & 11.5 & 11.0 & 10.5 & 10.1 & 10.6 & NS \\
\hline Median & 11.8 & 10.2 & 10.0 & 9.7 & 10.0 & \\
\hline 25th percentile & 10.2 & 7.5 & 7.8 & 7.9 & 7.8 & \\
\hline 75th percentile & 14.2 & 12.9 & 12.5 & 12.0 & 12.4 & \\
\hline \multicolumn{7}{|c|}{ Average daily total iron excluding supplements (mg) } \\
\hline Mean & 11.8 & 13.0 & 13.9 & 15.0 & 13.8 & $<0.0001$ \\
\hline Median & 11.8 & 12.3 & 13.1 & 14.3 & 13.2 & \\
\hline 25th percentile & 10.6 & 9.7 & 10.8 & 12.1 & 10.7 & \\
\hline 75th percentile & 14.4 & 14.8 & 16.1 & 17.2 & 16.0 & \\
\hline
\end{tabular}

ANOVA - one-way analysis of variance; NS - not significant. 
Table 4 Mean red and processed meat (RPM) consumption, iron intake and sources of iron according to level of RPM consumed (women only)

\begin{tabular}{|c|c|c|c|c|c|c|}
\hline & \multicolumn{4}{|c|}{ RPM consumption } & \multirow[b]{2}{*}{$\begin{array}{l}\text { Group total } \\
(n=838)\end{array}$} & \multirow[b]{2}{*}{$\begin{array}{r}P \text {-value } \\
\text { (ANOVA }\end{array}$} \\
\hline & $\begin{array}{l}\text { Non-consumers } \\
(n=19)\end{array}$ & $\begin{array}{l}<90 \mathrm{~g} \mathrm{day}^{-1} \\
(n=578)\end{array}$ & $\begin{array}{c}90-140 \mathrm{~g} \mathrm{day}^{-1} \\
(n=178)\end{array}$ & $\begin{array}{l}>140 \text { g day }^{-1} \\
(n=63)\end{array}$ & & \\
\hline \multicolumn{7}{|c|}{ RPM consumption (g day ${ }^{-1}$ ) } \\
\hline Mean & 0 & 52 & 109 & 176 & 72 & \multirow[t]{4}{*}{$<0.0001$} \\
\hline Median & 0 & 54 & 108 & 163 & 66 & \\
\hline 25th percentile & 0 & 35 & 98 & 153 & 43 & \\
\hline 75th percentile & 0 & 70 & 119 & 195 & 96 & \\
\hline \multicolumn{7}{|c|}{ Iron from RPM (mg) } \\
\hline Mean & 0 & 1.5 & 2.9 & 4.0 & 1.9 & \multirow[t]{4}{*}{$<0.0001$} \\
\hline Median & 0 & 1.3 & 2.6 & 3.7 & 1.6 & \\
\hline 25th percentile & 0 & 0.9 & 2.0 & 3.1 & 1.0 & \\
\hline 75th percentile & 0 & 1.9 & 3.2 & 4.4 & 2.6 & \\
\hline \multicolumn{7}{|c|}{ Iron from poultry (mg) } \\
\hline Mean & 0.1 & 0.2 & 0.1 & 0.2 & 0.2 & \multirow[t]{4}{*}{ NS } \\
\hline Median & 0 & 0.1 & 0.1 & 0.1 & 0.1 & \\
\hline 25th percentile & 0 & 0 & 0 & 0 & 0 & \\
\hline 75th percentile & 0.1 & 0.2 & 0.2 & 0.3 & 0.2 & \\
\hline \multicolumn{7}{|c|}{ Iron from non-meat sources (mg) } \\
\hline Mean & 10.6 & 8.7 & 8.3 & 8.1 & 8.6 & \multirow[t]{4}{*}{ NS } \\
\hline Median & 9.1 & 7.9 & 7.6 & 7.9 & 7.8 & \\
\hline 25th percentile & 6.9 & 5.9 & 6.2 & 5.8 & 6.0 & \\
\hline 75th percentile & 11.2 & 10.1 & 9.7 & 9.6 & 9.9 & \\
\hline \multicolumn{7}{|c|}{ Average daily total iron excluding supplements (mg) } \\
\hline Mean & 10.7 & 10.4 & 11.3 & 12.3 & 10.7 & \multirow[t]{4}{*}{0.002} \\
\hline Median & 9.2 & 9.6 & 10.6 & 11.4 & 10.0 & \\
\hline 25th percentile & 6.9 & 7.5 & 8.9 & 9.6 & 8.1 & \\
\hline 75th percentile & 11.3 & 12.3 & 12.6 & 13.9 & 12.5 & \\
\hline
\end{tabular}

ANOVA - one-way analysis of variance; NS - not significant.

Applying this reasoning to the subjects in our study, low RPM consumption was associated with a greater risk of low iron intake (Fig. 2). Women who ate least meat $\left(<90 \mathrm{~g} \mathrm{day}^{-1}\right)$ had nearly three times the risk of iron intake below the LRNI compared with high consumers of RPM $\left(>140 \mathrm{~g} \mathrm{day}^{-1}\right)(P<0.001)$. Men who ate no RPM

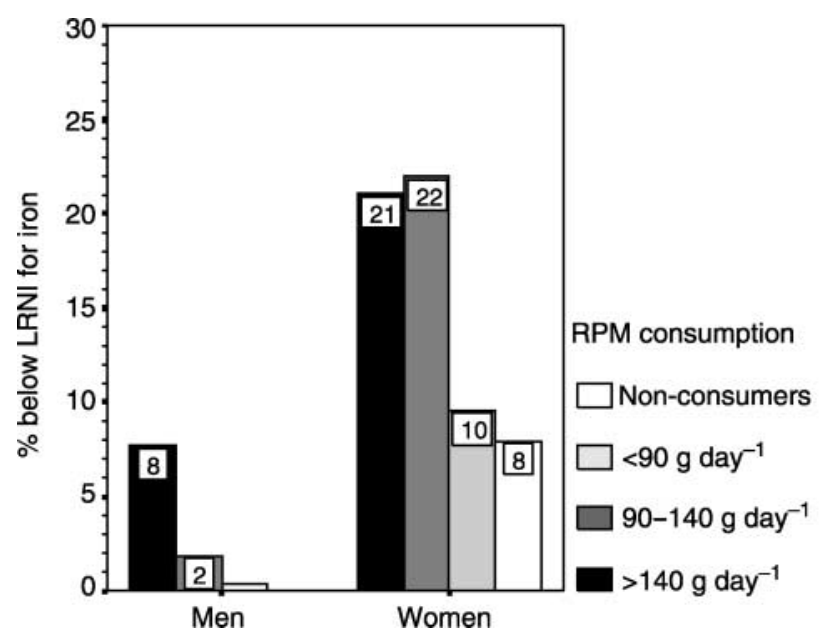

Fig. 2 Prevalence of low iron intake (percentage below Lower Reference Nutrient Intake (LRNI) for iron) by red and processed meat (RPM) consumption level $(P=0.005$ for men, $n=836$; $P<0.001$ for women, $n=838$ ) also had a much higher risk of iron intake below the LRNI than those men who ate RPM $(P=0.005)$.

\section{Estimation of the amount of iron absorbed}

The estimation of low iron intake used above is based only on the total amount of iron consumed in relation to theoretical requirements. To gain an estimate of the amount of iron likely to be absorbed we applied the Hallberg equations, which allow for the fact that the percentage of iron absorbed is highly dependent on iron stores, to our data (see Methods). According to these equations, the women in our study (who tend to have lower levels of serum ferritin than the men) were estimated to absorb (on average) 18\% of the total iron consumed, while the men in our study absorbed on average $9 \%$ of total iron consumed (Table 5). However, both values differ markedly from person to person depending on the state of iron depletion.

\section{Estimation of potential risk of negative iron balance}

The estimates of iron absorbed were then compared with estimated minimal iron losses in the groups (see Methods). We classified the population at potential risk of negative iron balance as the percentage of individuals with estimated AbFe below these minimal iron losses. This provides a rough indication of the extent of negative iron 
Table 5 Estimated iron absorption (amounts and percentages) by level of red and processed meat (RPM) consumption

\begin{tabular}{|c|c|c|c|c|c|c|c|}
\hline & & \multicolumn{4}{|c|}{ RPM consumption } & \multirow[b]{2}{*}{ Group total } & \multirow[b]{2}{*}{$P$-value (ANOVA) } \\
\hline & & Non-consumers & $<90$ g day $^{-1}$ & $90-140 \mathrm{~g} \mathrm{day}^{-1}$ & $>140 \mathrm{~g} \mathrm{day}^{-1}$ & & \\
\hline \multirow{4}{*}{$\begin{array}{l}\text { Men } \\
\text { Estimated total iron } \\
\text { absorbed }\left(\mathrm{mg} \mathrm{day}^{-1}\right)\end{array}$} & & $n=13$ & $n=335$ & $n=264$ & $n=224$ & $n=836$ & \\
\hline & Mean & 1.02 & 1.21 & 1.24 & 1.29 & 1.24 & 0.683 \\
\hline & SE & 0.18 & 0.06 & 0.06 & 0.05 & 0.03 & \\
\hline & Median & 0.85 & 0.85 & 1.02 & 1.10 & 0.98 & \\
\hline \multirow[t]{3}{*}{$\%$ Iron absorbed } & Mean & 8.3 & 9.2 & 8.7 & 8.6 & 8.9 & 0.690 \\
\hline & SE & 1.3 & 0.4 & 0.3 & 0.4 & 0.2 & \\
\hline & Median & 6.8 & 6.2 & 6.6 & 7.0 & 6.7 & \\
\hline \multirow{4}{*}{$\begin{array}{l}\text { Women } \\
\text { Estimated total iron } \\
\left.\text { absorbed (mg day }{ }^{-1}\right)\end{array}$} & & $n=19$ & $n=578$ & $n=178$ & $n=63$ & $n=838$ & \\
\hline & Mean & 2.23 & 1.91 & 2.07 & 2.10 & 1.97 & 0.683 \\
\hline & SE & 0.36 & 0.07 & 0.11 & 0.16 & 0.06 & \\
\hline & Median & 1.76 & 1.27 & 1.66 & 1.62 & 1.38 & \\
\hline \multirow[t]{3}{*}{$\%$ Iron absorbed } & Mean & 21.9 & 18.3 & 19.1 & 17.2 & 18.5 & 0.690 \\
\hline & SE & 3.5 & 0.6 & 1.0 & 1.2 & 0.5 & \\
\hline & Median & 16.0 & 13.4 & 14.1 & 14.6 & 13.7 & \\
\hline
\end{tabular}

ANOVA - one-way analysis of variance; SE - standard error.

balance in the population, although clearly it cannot indicate negative iron balance in any individual, whose requirement is unknown.

The risk of negative iron balance was inversely related to RPM consumption, in both men and women (Fig. 3). Stratification by age group (under 50 vs. 50 years and over) showed that this was not an artefact of a difference in age distribution (and iron requirements) between RPM groups (Table 6).

\section{Iron status according to RPM consumption}

The direct association between RPM consumption and iron status was examined using the serum measurements of $\mathrm{Hb}$ and ferritin at various cut-offs. There were downward trends (reducing prevalence of low iron stores or anaemia with increasing RPM) for most status cut-offs although some failed to reach statistical

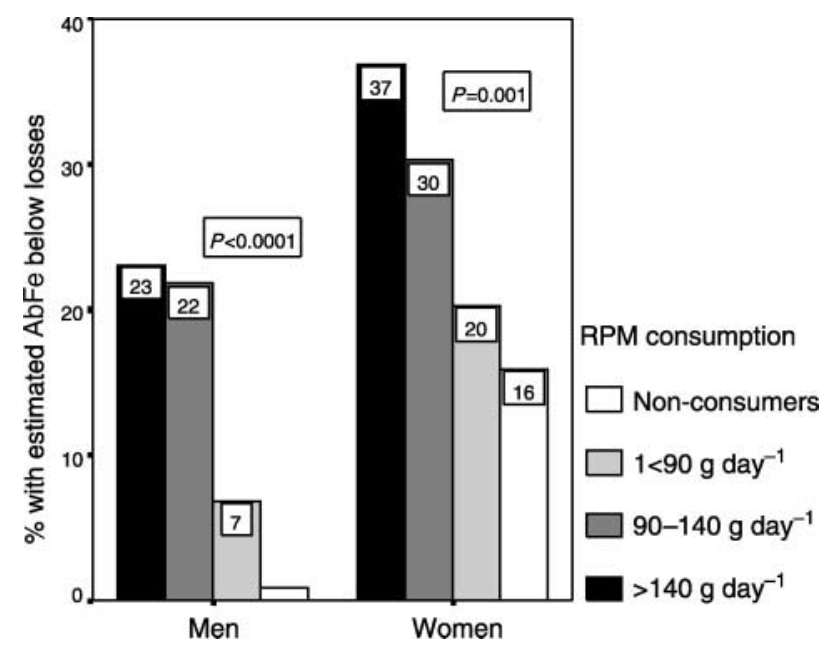

Fig. 3 Men and women at potential risk of negative iron balance (percentage with estimated absorbed iron ( $\mathrm{AbFe}$ ) below minimal estimated losses, see text) by red and processed meat (RPM) consumption level significance. Among women, for example, there was a tendency towards low ferritin levels with reduced consumption of RPM. Anaemia was significantly more common among women non-consumers (38\%) and low RPM consumers (12\%), compared with high consumers (6\%) $(P=0.009$ for linear trend). Among men, the prevalence of borderline iron stores (serum ferritin $<25 \mu \mathrm{gl}^{-1}$ ) was twice as high among low consumers as among high consumers of RPM ( $7 \% \mathrm{vs}$. 3\%; $P=0.011$ ) (Table 7).

\section{Discussion}

\section{Considerations of assumptions made in our study}

Until the publication of the new NDNS of adults in 2003, the survey used for this study (DNSBA) ${ }^{9}$ remains the most recent nation-wide dietary survey of individuals aged 16-64 years in Britain. Using these data we have shown that RPM consumption estimated from 7-day records is positively associated with both iron intake and iron status. We have suggested that the enhanced absorption that arises from low iron stores is not adequate to satisfy the iron requirements of some, and that the potential risk of negative iron balance is more pronounced in men and women who eat little or no RPM. Furthermore, actual measurements of iron status in this population support the conclusion that a significant reduction in red meat consumption could exacerbate the problem of poor iron status, particularly for women of reproductive age.

Due to the detailed nature of dietary recording, misreporting is a potential problem in all such surveys and could have an impact on the recorded intake of all dietary constituents, resulting in an underestimation of RPM and iron intakes. However, misreporting is unlikely to affect the validity of our conclusions adversely, because (1) the estimation of RPM was used merely to classify individuals into four groups 
Table 6 Percentage of men and women in two age groups who are at potential risk of negative iron balance (estimated absorbed iron below minimal estimated losses) by level of red and processed meat (RPM) consumption

\begin{tabular}{|c|c|c|c|c|c|c|c|}
\hline & & \multicolumn{4}{|c|}{ RPM consumption } & \multirow[b]{2}{*}{ Group total } & \multirow[b]{2}{*}{$P$-value ${ }^{\star}$ (chi square) } \\
\hline & & Non-consumers & $<90$ g day $^{-1}$ & $90-140$ g day $^{-1}$ & $>140 \mathrm{~g} \mathrm{day}^{-1}$ & & \\
\hline \multicolumn{8}{|l|}{ Men } \\
\hline $16-49$ years & $\begin{array}{l}n \\
\%\end{array}$ & $\begin{array}{l}13 \\
23\end{array}$ & $\begin{array}{r}227 \\
22\end{array}$ & $\begin{array}{r}196 \\
7\end{array}$ & $\begin{array}{r}168 \\
1\end{array}$ & $\begin{array}{r}604 \\
11\end{array}$ & $<0.0001$ \\
\hline $50-64$ years & $\begin{array}{l}n \\
\%\end{array}$ & $\begin{array}{l}0 \\
-\end{array}$ & $\begin{array}{r}108 \\
24\end{array}$ & $\begin{array}{r}68 \\
6\end{array}$ & $\begin{array}{r}56 \\
2\end{array}$ & $\begin{array}{r}232 \\
13\end{array}$ & $<0.0001$ \\
\hline \multicolumn{8}{|l|}{ Women } \\
\hline $16-49$ years & $\begin{array}{l}n \\
\%\end{array}$ & $\begin{array}{l}15 \\
40\end{array}$ & $\begin{array}{r}419 \\
32\end{array}$ & $\begin{array}{r}132 \\
24\end{array}$ & $\begin{array}{l}51 \\
18\end{array}$ & $\begin{array}{r}617 \\
29\end{array}$ & 0.008 \\
\hline $50-64$ years & $\begin{array}{l}n \\
\%\end{array}$ & $\begin{array}{r}4 \\
25\end{array}$ & $\begin{array}{r}159 \\
27\end{array}$ & $\begin{array}{r}46 \\
9\end{array}$ & $\begin{array}{r}12 \\
8\end{array}$ & $\begin{array}{r}221 \\
22\end{array}$ & 0.009 \\
\hline
\end{tabular}

* $P$ for linear trend.

and (2) the dietary guidelines for iron rely heavily on data from such surveys and therefore are also prone to bias in the same direction. Misclassification of people who ate more or less red meat than usual during the survey week would reduce the power of the survey to detect associations with iron status, rather than producing a spurious positive result.

Our estimates of haem and non-haem iron intake are proportions of the DNSBA data on iron intake and are consistent with the values of other studies ${ }^{15,16}$. Errors arising from under- or overestimation of the haem iron content of different meat-containing food groups would have only a small effect on the estimates of absorbed iron because (1) $60 \%$ of the iron in meat is non-haem and (2) the distinction between the absorption of haem and non-haem iron reduces as iron status becomes more critical (serum ferritin $<25 \mu \mathrm{gl}^{-1}$ ). Since a substantial proportion of women have serum ferritin values in this range, our results are likely to be less prone to this source of error and thus more reliable for women than for men.
Ideally, to estimate iron absorption, one should evaluate the enhancing and inhibiting effects of other dietary components within the meal. Indeed, others have recently attempted to derive absorption algorithms that are more sophisticated than used here and predict the absorbable iron from mixed diets ${ }^{21,22}$ and meals ${ }^{21,23}$. Owing to the limited nature of data in the public domain in this survey, our estimate could not adjust for the effects of components that enhance or inhibit iron absorption within the meal, although it did account for two prime influences: the form of iron (haem or non-haem) and the iron status of the individual. Reassuringly for the present study, Hallberg and Hulthen have since reported that iron absorption estimated using these formulae is not significantly different from that calculated from the individual meals consumed $^{21}$. In any event we believe that such formulae represent an advance on the uniform bioavailability factor of $15 \%$ used in the DRV report ${ }^{20}$ and elsewhere ${ }^{24}$.

We have drawn heavily on the data and calculations used by the Department of Health in $1991^{20}$ for our

Table 7 Iron status from serum measurements (percentages of men and women with low ferritin or low haemoglobin (Hb) value) by level of red and processed meat (RPM) consumption

\begin{tabular}{|c|c|c|c|c|c|c|c|}
\hline & & \multicolumn{4}{|c|}{ RPM consumption } & \multirow[b]{2}{*}{ Group total } & \multirow[b]{2}{*}{$P$-value (chi square) } \\
\hline & & Non-consumers & $<90$ g day $^{-1}$ & $90-140 \mathrm{~g} \mathrm{day}^{-1}$ & $>140 \mathrm{~g} \mathrm{day}^{-1}$ & & \\
\hline \multicolumn{8}{|l|}{ Men } \\
\hline Low iron stores & $n$ & 13 & 335 & 264 & 224 & 836 & \\
\hline Ferritin $<25 \mu \mathrm{gI}^{-1}$ & $\%$ & 8 & 7 & 5 & 3 & 5 & $0.011^{*}$ \\
\hline Ferritin $<20 \mu \mathrm{gl}^{-1}$ & $\%$ & - & 4 & 3 & 2 & 3 & $0.19^{*}$ \\
\hline Ferritin $<15 \mu \mathrm{gl}^{-1}$ & $\%$ & - & 4 & 2 & 1 & 2 & 0.10 \\
\hline Anaemia & $n$ & 10 & 295 & 233 & 203 & 741 & \\
\hline $\mathrm{Hb}<13 \mathrm{~g} \mathrm{dl}^{-1}$ & $\%$ & - & 1 & 1 & 1 & 1 & NS \\
\hline \multicolumn{8}{|l|}{ Women } \\
\hline Low iron stores & $n$ & 19 & 578 & 178 & 63 & 838 & \\
\hline Ferritin $<20 \mu \mathrm{gl}^{-1}$ & $\%$ & 37 & 27 & 27 & 19 & 26 & NS $(0.22)^{\star}$ \\
\hline Ferritin $<15 \mu \mathrm{gl}^{-1}$ & $\%$ & 26 & 19 & 18 & 11 & 18 & NS $(0.14)$ \\
\hline Ferritin $<10 \mu \mathrm{gl}^{-1}$ & $\%$ & 16 & 11 & 11 & 3 & 11 & NS (0.09) \\
\hline Anaemia & $n$ & 16 & 507 & 170 & 54 & 747 & \\
\hline $\mathrm{Hb}<12 \mathrm{~g} \mathrm{dl}^{-1}$ & $\%$ & 38 & 12 & 14 & 6 & 13 & 0.009 \\
\hline
\end{tabular}

${ }^{*} P$ for linear trend; NS - not significant. 
estimations of the potential risk of negative iron balance. Mean iron losses in men are the so-called basal losses (epithelial and endothelial cells as well as bleedings of red cells from mucosal surfaces), estimated ${ }^{25}$ at around $14 \mu \mathrm{g}$ per $\mathrm{kg}$ body weight using the radio iron isotope ${ }^{55} \mathrm{Fe}$. In women of reproductive age, there are additional iron losses due to menstruation. There are few published data on menstrual blood loss in the UK and the current DRVs were based on measurements of mean menstrual blood loss of $43 \mathrm{ml}$ obtained from a Swedish study carried out in the $1960 \mathrm{~s}^{26,27}$. It was reported that blood loss could range from a few millilitres to $400 \mathrm{ml}$ per period. There is a marked variation in menstrual blood loss between different women ${ }^{28,29}$, but it is relatively constant in an individual woman throughout fertile life ${ }^{26}$. Since this time, the increased use of oral contraceptives may have reduced average blood losses and hence iron requirements ${ }^{30}$. A recent, as yet unpublished UK study ${ }^{31}$ has generated data from direct measurements of menstrual blood loss and has suggested that it may, indeed, be slightly less now. They studied 90 women aged between 18 and 45 years and found a mean blood loss of $31 \mathrm{ml}$ (range 1-129 $\mathrm{ml}$ ). The trend was for women using oral contraceptives to have a lower menstrual blood loss than non-users of oral contraceptives. The fact that menstrual losses and hence iron losses are actually lower than those assumed by COMA justifies our conservative approach of calculating the proportion of subjects at potential risk for negative iron balance on the basis of minimal blood losses.

\section{Other studies reporting an association between meat consumption and iron status}

Several studies in other countries have shown the beneficial effect of meat eating on iron status in adults. Premenopausal American women were split into three groups based on their habitual consumption of red meat, fish and/or poultry or lacto-ovo vegetarian sources of protein. No differences were seen in total iron intake but those women consuming red meat as their predominant source of protein demonstrated superior iron status, especially reflected by higher serum ferritin concentrations. These authors concluded that the form rather than the amount of dietary iron appeared to be most influential on iron status ${ }^{32}$. Another study divided young Spanish women on the basis of their meat consumption (above or below $100 \mathrm{~g} \mathrm{day}^{-1}$ ) and concluded that because high meat consumers showed higher levels of $\mathrm{Hb}$, restriction of meat and meat products could have negative repercussions on the nutritive status and health of certain groups within the population, particularly young females ${ }^{33}$. A study of Dutch adults showed that iron status was correlated negatively with the vegetable fraction of the diet, and positively with factors from the animal fraction (haem iron, animal protein, meat $)^{34}$. Meat was also one of the factors affecting the concentrations of serum ferritin in healthy Australians ${ }^{35}$. Serum ferritin was positively correlated with meat, fish and total iron intake in a national sample of adults living in France and participating in the SU.VI.MAX cohort $^{36}$. Low meat/fish/poultry intake was also shown to be the dietary factor that correlated best with mild iron deficiency in premenopausal adult New Zealand women ${ }^{8}$.

\section{Implications of reduction in red meat consumption}

The data on low RPM consumers $\left(<90 \mathrm{~g} \mathrm{day}^{-1}\right)$ provide one scenario of the impact of truncating the distribution of RPM consumption to a maximum of $90 \mathrm{~g} \mathrm{day}^{-1}$. In practice, a continuation of the trend away from red meat will not merely truncate the distribution but shift it to the left, resulting in an increased number of 'new' nonRPM eaters (who may substitute poultry and fish for RPM) and an increased number of 'true' vegetarians. Our method can only model the effect by comparing groups with different RPM status. How then do our results compare to studies that have examined the iron status of 'true' vegetarians and omnivores?

Some studies suggest that long-term lacto-ovo vegetarians and female vegans, even with a high fibre (and hence phytate) intake, generally have a similar iron status to omnivores ${ }^{37,38}$. However, most studies indicate that vegetarians have reduced iron stores (as measured by serum ferritin levels) ${ }^{39-42}$. Some studies ${ }^{42,43}$ have found evidence of lower $\mathrm{Hb}$ levels among vegetarian children, although in Nelson et al.'s study this was only true among white vegetarian girls, and not of their Asian counterparts ${ }^{44}$. Importantly, these differences in iron status did not appear to be explained by lower iron intakes, which were either similar between vegetarians and omnivores ${ }^{41-43}$ or, in one case, higher among vegetarians ${ }^{45}$. The authors suggested dietary advice was needed to ensure optimal absorption of iron.

These inconsistent conclusions probably reflect three issues. First, the term vegetarianism covers a wide range of dietary practices and people often define themselves as vegetarian when they actually eat meat, such as ham, occasionally. Second, the inconsistency could reflect the different degrees to which vegetarians make a conscious effort to ensure their diets contain an adequate amount of iron. Some vegetarians have a dietary pattern with a balance of fruit, vegetables, pulses and nuts; some choose to take iron supplements, others do neither of these. Third, the inconsistency of conclusions on whether vegetarianism results in iron inadequacy could reflect the body's longterm capacity to adapt to lower iron intakes by increasing absorption. Vegetarians of longer standing would be expected to have better iron status than new vegetarians.

Our comparison of people who eat different amounts of RPM might give a truer picture of the implications of reduced intake of RPM on iron inadequacy than comparisons of vegetarians and omnivores. If omnivores simply decide to eat less RPM because, say, they are worried about BSE or colon cancer, they are less likely to make any conscious efforts to ensure iron status 
and so they might be more at risk from iron inadequacy than more dedicated life-long vegetarians.

In our modelling techniques, we have taken into account two of the most important determinants of iron absorption: the amount of haem versus non-haem iron, and the host-related increase in iron absorption with poorer iron status. Our results, although based on estimates of iron absorption, indicate that the increased absorptive efficiency in those with low iron stores is still likely to be insufficient to supply the iron needs of a small but significant proportion of young women.

\section{Trends in meat intakes}

Data from the National Food Survey suggest that carcass meat intakes may have fallen by 20\% since 1989 and that most of the decline in the consumption of carcass meat can be explained by a fall in the consumption of beef and veal $^{1}$. The rise in consumption of poultry and fish is insufficient to compensate for this trend. This information on the decline in household meat purchases is backed up by results from the Food Standards Agency survey of consumer attitudes ${ }^{46}$, which showed that $19 \%$ of respondents said they ate less meat than a year ago, an increase of $3 \%$ over the previous year. A new dietary survey of UK adults was undertaken in 2001 and results will be available in 2003. It is likely that intakes of haem iron will have fallen substantially since 1986/7 and that low iron status in certain population groups will be more evident. Dietary messages need to take account of these trends and provide appropriate advice, which might include emphasising the value of meat as a source of readily available iron and communicating the importance of enhancers and inhibitors of absorption of non-haem iron.

\section{Acknowledgements}

Both authors are independent consultants. Material from the Dietary and Nutritional Survey of British Adults, made available through the Office of Population Censuses and Surveys, the Ministry of Agriculture, Fisheries and Food and the Department of Health, and obtained from the ESRC Data Archive, was used with permission of the Controller of The Stationery Office.

Competing interests: This study was commissioned by the Meat and Livestock Commission.

\section{References}

1 Robinson F. The nutritional contribution of meat to the British diet: recent trends and analyses. Br. Nutr. Found. Nutr. Bull. 2002; 26: 283-93.

2 Ministry of Agriculture, Fisheries and Food. National Food Survey, 1999. London: HMSO, 2000.

3 Felton JS, Knize MG. Heterocyclic-amine mutagens/ carcinogens in foods. In: Cooper CS, Grover PL, eds. Chemical Carcinogenesis and Mutagenesis. Handbook of Experimental Pharmacology. Vol. 1. Berlin: Springer-Verlag, 1990; 471-502.
4 Willett WC, Stampfer MJ, Colditz GA, Rosner BA, Speizer FE. Relation of meat, fat, and fiber intake to the risk of colon cancer in a prospective study among women. N. Engl. J. Med. 1990; 323: 1664-72.

5 Giovannucci E, Rimm EB, Stampfer MJ, Colditz GA, Ascherio A, Willett WC. Intake of fat, meat, and fiber in relation to risk of colon cancer in men. Cancer Res. 1994; 54: 2390-7.

6 World Cancer Research Fund. Food, Nutrition and The Prevention of Cancer: A Global Perspective. Washington, DC: American Institute for Cancer Research, 1997.

7 Department of Health. Nutritional Aspects of the Development of Cancer. Report of the Working Group on Diet and Cancer, Committee on the Medical Aspects of Food and Nutrition Policy. Report on Health and Social Subjects No. 48. London: The Stationery Office, 1998.

8 Heath A-LM, Skeaff CM, Williams S, Gibson RL. The role of blood loss and diet in the aetiology of mild iron deficiency in premenopausal adult New Zealand women. Public Health Nutr. 2001; 4(2): 197-206.

9 Gregory J, Foster K, Tyler H, Wiseman M. Dietary and Nutritional Survey of British Adults. Office of the Population Censuses and Surveys, Social Survey Division. London: HMSO, 1990.

10 Dallman PR. Biochemical basis for the manifestations of iron deficiency. Annu. Rev. Nutr. 1986; 6: 13-40.

11 Ashwell MA, ed. Iron. Nutritional and Physiological Significance. British Nutrition Foundation Task Force. London: British Nutrition Foundation, 1995.

12 Hurrell RF. Bioavailability of iron. Eur. J. Clin. Nutr. 1997; 51(Suppl. 1): S4-8.

13 Elliott C. Eat less red meat to cut cancer risk, urges report. The Guardian. London: 1997.

14 Monsen ER, Balintfy JL. Calculating dietary iron bioavailability: refinement and computerization. J. Am. Diet. Assoc. 1982; 80(4): 307-11.

15 Bull NL, Buss DH. Haem and non-haem iron in British household diets. J. Hum. Nutr. 1980; 34(2): 141-5.

16 Finch S, Doyle W, Lowe C, Bates C, Prentice A, Smithers G, et al. National Diet and Nutrition Survey: People aged 65 years and over. Vol. 1. Report of the Diet and Nutrition Survey. London: The Stationery Office, 1998

17 Hallberg L, Hulten L, Gramatkovski E. Iron absorption from the whole diet in men: how effective is the regulation of iron absorption? Am. J. Clin. Nutr. 1997; 66(2): 347-56.

18 Hulten L, Gramatkovski E, Gleerup A, Hallberg L. Iron absorption from the whole diet. Relation to meal composition, iron requirements and iron stores. Eur. J. Clin. Nutr. 1995; 49(11): 794-808.

19 Monsen ER, Hallberg L, Lagrisse M, Hegsted DM, Cook JD, Mertz W, et al. Estimation of available dietary iron. Am. J. Clin. Nutr. 1978; 31(1): 134-41.

20 Department of Health. Dietary Reference Values for Food Energy and Nutrients for the United Kingdom. London: HMSO, 1991.

21 Hallberg L, Hulthen L. Prediction of dietary iron absorption: an algorithm for calculating absorption and bioavailability of dietary iron. Am.J. Clin. Nutr. 2000; 71(5): 1147-60.

22 Cook JD, Reddy MB. Effect of ascorbic acid intake on nonheme-iron absorption from a complete diet. Am. J. Clin. Nutr. 2001; 73(1): 93-8.

23 Reddy MB, Hurrell RF, Cook JD. Estimation of nonheme-iron bioavailability from meal composition. Am. J. Clin. Nutr. 2000; 71(4): 937-43.

24 Food and Agriculture Organization (FAO). Requirements of Vitamin A, Iron, Folate and $B_{12}$. Report of a Joint FAO/WHO Consultation. Rome: FAO, 1988.

25 Green R, Charlton R, Seftel H, Bothwell T, Mayet F, Adams B, 
et al. Body iron excretion in man: a collaborative study. Am. J. Med. 1968; 45(3): 336-53.

26 Hallberg L, Hogdahl M, Nilsson L, Rybo G. Menstrual blood loss - a population study. Variation at different ages and attempts to define normality. Acta Obstet. Gynecol. Scand. 1966; 45(3): 320-51.

27 Hallberg L, Rossander-Hulten L. Iron requirements in menstruating women. Am. J. Clin. Nutr. 1991; 54(6): $1047-58$.

28 Cole SK, Billewicz WZ, Thomson AM. Sources of variation in menstrual blood loss. J. Obstet. Gynaecol. Br. Commonw. 1971; 78(10): 933-9.

29 Hefnawi F, El-Zayat AF, Yacout MM. Physiologic studies of menstrual blood loss. I. Range and consistency of menstrual blood loss in and iron requirements of menstruating Egyptian women. Int. J. Gynaecol. Obstet. 1980; 17(4): 343-8.

30 Guillebaud J, Bonnar J, Morehead J, Matthews A. Menstrual blood-loss with intrauterine devices. Lancet 1976; 1(7956): 387-90.

31 Harvey L. The bioavailability of iron, zinc and copper in meat containing and vegetarian diets in the United Kingdom. Unpublished, 2002.

32 Worthington-Roberts BS, Breskin MW, Monsen ER. Iron status of premenopausal women in a university community and its relationship to habitual dietary sources of protein. Am. J. Clin. Nutr. 1988; 47(2): 275-9.

33 Ortega RM, Lopez-Sobaler AM, Requejo AM, Quintas ME, Gaspar MJ, Andres $\mathrm{P}$, et al. The influence of meat consumption on dietary data, iron status and serum lipid parameters in young women. Int. J. Vitam. Nutr. Res. 1998; 68(4): 255-62.

34 Brussaard JH, Brants HA, Bouman M, Lowik MR. Iron intake and iron status among adults in the Netherlands. Eur.J. Clin. Nutr. 1997; 51(Suppl. 3): S51-8.

35 Leggett BA, Brown NN, Bryant SJ, Duplock L, Powell LW, Halliday JW. Factors affecting the concentrations of ferritin in serum in a healthy Australian population. Clin. Chem. 1990; 36(7): 1350-5.

36 Galan P, Yoon HC, Preziosi P, Viteri F, Valeix P, Fieux B, et al. Determining factors in the iron status of adult women in the SU.VI.MAX study. SUpplementation en VItamines et Mineraux AntioXydants. Eur. J. Clin. Nutr. 1998; 52(6): 383-8.

37 Craig WJ. Iron status of vegetarians. Am. J. Clin. Nutr. 1994; 59(Suppl. 5): 1233S-7S.

38 Haddad EH, Berk LS, Kettering JD, Hubbard RW, Peters WR Dietary intake and biochemical, hematologic, and immune status of vegans compared with nonvegetarians. Am. J. Clin. Nutr. 1999; 70(Suppl. 3): 586S-93S.

39 Faber M, Gouws E, Benade AJ, Labadarios D. Anthropometric measurements, dietary intake and biochemical data of South African lacto-ovovegetarians. S. Afr. Med. J. 1986; 69(12): 733-8.

40 Helman AD, Darnton-Hill I. Vitamin and iron status in new vegetarians. Am. J. Clin. Nutr. 1987; 45(4): 785-9.

41 Reddy S, Sanders TA. Haematological studies on pre-menopausal Indian and Caucasian vegetarians compared with Caucasian omnivores. Br. J. Nutr. 1990; 64(2): $331-8$.

42 Thane CW, Bates CJ. Iron intakes and status in adolescent British girls according to meat consumption [abstract]. Ann. Nutr. Metab. 2001; 45(Suppl. 1): 480-1.

43 Nathan I, Hackett AF, Kirby S. The dietary intake of a group of vegetarian children aged 7-11 years compared with matched omnivores. Br. J. Nutr. 1996; 75(4): 533-44.

44 Nelson M, Bakaliou F, Trivedi A. Iron-deficiency anaemia and physical performance in adolescent girls from different ethnic backgrounds. Br. J. Nutr. 1994; 72(3): 427-33.

45 Alexander D, Ball MJ, Mann J. Nutrient intake and haematological status of vegetarians and age-sex matched omnivores. Eur. J. Clin. Nutr. 1994; 48: 538-46.

46 Food Standards Agency. Second Consumer Attitudes Survey [online]. Available at http://www.foodstandards.gov.uk/ yourviews/surveys/foodsafety-nutrition-diet/47020, 2002. 